\title{
1 Four years of experimental warming do not modify the interaction between subalpine
}

2 shrub species

3 Alba Anadon-Rosell (1,2*), Josep M. Ninot (1,2), Sara Palacio (3), Salvador Nogués (1), Empar

4 Carrillo $(1,2)$

5

6 Affiliations

7 (1) Department of Evolutionary Biology, Ecology and Environmental Sciences, University of

8 Barcelona, Av. Diagonal 643, 08028 Barcelona, Catalonia, Spain.

9 (2) Biodiversity Research Institute (IRBio), University of Barcelona, Av. Diagonal 643, 08028

10 Barcelona, Catalonia, Spain.

11 (3) Instituto Pirenaico de Ecología (IPE-CSIC), Av. Nuestra Señora de la Victoria 16, 22700

12 Jaca (Huesca), Spain.

$13 *$ Corresponding author a.anadon@ub.edu

14 Keywords: dwarf shrub, plant interactions, Pyrenees, Rhododendron ferrugineum, treeline,

15 Vaccinium myrtillus, Vaccinium uliginosum, passive warming

16 Abbreviations: AG (above-ground), BG (below-ground), $\delta^{13} \mathrm{C}$ (carbon isotope composition),

$17 \delta^{15} \mathrm{~N}$ (nitrogen isotope composition) 


\section{Abstract}

24 Climate warming can lead to changes in alpine plant species' interactions through the

25 amelioration of environmental conditions. Consistent with the stress-gradient hypothesis, many

26 studies have shown that release from environmental stress can lead to increased competition.

27 However, most of these studies were based on neighbour removal experiments, whereas the response of natural communities has received less attention. We explored the effects of four years of experimental warming with open-top chambers on Vaccinium myrtillus stands with different neighbouring shrub species at the Pyrenean treeline. Our aim was to find possible shifts in the interaction between $V$. myrtillus and its neighbours following warming that were demonstrated through changes in $V$. myrtillus performance. We examined the effects of warming on above-ground growth parameters, below-ground biomass and the $\mathrm{C}$ and $\mathrm{N}$ content and isotope composition of $V$. myrtillus growing in pure stands, in stands mixed with Vaccinium uliginosum, and in stands mixed with Rhododendron ferrugineum. We also analysed variations in soil $\mathrm{N}$ pools and rhizospheric soil $\mathrm{C} / \mathrm{N}$ ratios, and evaluated the effects of warming on the neighbouring $V$. uliginosum in mixed plots. Our results showed that warming induced positive changes in the above-ground growth of $V$. myrtillus, but not below-ground, while $V$. uliginosum did not respond to warming. Vaccinium myrtillus performance did not differ between stand

40 types under increased temperatures, which indicates that warming did not induce any shifts in

41 the interaction between $V$. myrtillus and its neighbours. These findings contrast with many

42 studies in which species interactions changed when environmental conditions were modified,

43 and shows that the interaction between our study species may not be altered with warmer

44 temperatures at the Pyrenean treeline. 
In the recent decades, climate warming and land-use change (i.e. abandonment of extensive grazing) have led to shrub encroachment processes in the treeline ecotone (Dullinger et al. 2003, Rundqvist et al. 2011, Ropars and Boudreau 2012). The forecasted global air temperature increase of $1.0-3.7^{\circ} \mathrm{C}$ by the end of the century (Collins et al. 2013) could accelerate these processes. This could have a dramatic impact on Arctic and alpine tundra ecosystems due to shifts in community composition and potential feedbacks to warming, such

54 as decreasing albedo or reducing radiative cooling at night or through the inputs of more

55 recalcitrant litter in the ecosystem (Hobbie 1996, Cornelissen et al. 2007, Myers-Smith et al.

56 2011, D’Odorico et al. 2013).

57 Many studies in Arctic and alpine ecosystems have shown the need to carry out species-

58 specific studies to understand vegetation changes with warming, since co-occurring species may

59 differ in their responses to increasing temperatures (Kudo and Suzuki 2003, Klanderud 2008,

60 Anadon-Rosell et al. 2014, Little et al. 2015, Yang et al. 2015). However, when studying

61 vegetation responses to temperature increase, it is also important to consider plant-plant

62 interactions, since they are one of the main drivers of community dynamics (Callaway and

63 Walker 1997). The stress-gradient hypothesis (SGH; Bertness and Callaway 1994) postulates

64 that competition is the major selective force in habitats with more benign environmental

65 conditions, whereas facilitation dominates in more severe environments. In fact, many studies in

66 cold regions across the globe have shown that plant interactions shift from facilitation to

67 competition as temperature increases, or in the opposite direction when temperature decreases

68 (Shevtsova et al. 1997, Choler et al. 2001, Klanderud 2005, Pugnaire et al. 2015, Wheeler et al.

692015 , Olsen et al. 2016, amongst others). Nevertheless, most of these studies involved plant

70 removal experiments, and studies focusing on the effects of temperature changes on plant

71 interactions within natural communities are scarce (but see Dormann et al. 2004). 

species are of great importance in terms of Arctic and alpine vegetation cover, structure and

74 functionality. They present a complex network of subterranean rhizomes bearing fine roots, and producing individual above-ground ramets. Thus, the below-ground system of clonal shrubs is essential for their persistence and vegetative expansion, as well as an important source of soil carbon (Cornelissen et al. 2014). Changes in the below-ground structure of dominant clonal shrubs could translate into major changes in the community and ecosystem structure and composition. Consequently, the study of below-ground responses to warming is an essential part of the complex responses to temperature increase in Arctic and alpine areas. However, the impacts of below-ground sampling and the difficulty encountered when attempting to identify and separate roots from different species, together with the compromise of having studies running for the longest term possible, explain why warming experiments including both aboveand below-ground plant measurements are less common (but see Hollister and Flaherty 2010 and Yang et al. 2015, amongst others). nitrogen availability and, ultimately, plant growth (Bardgett and Wardle 2010). Several studies in cold ecosystems have found an increase in the $\mathrm{N}$ pool size with warming (Chapin et al. 1995, Hartley et al. 1999, Dijkstra et al. 2010, Dawes et al. 2011, Bai et al. 2013), which has been related to an increase in the mineralization and decomposition processes at higher temperatures. Since co-occurring species show different $\mathrm{N}$ preferences and $\mathrm{N}$-acquisition strategies (Körner et al. 2003, Pornon et al. 2007), shifts in the N pools can lead to changes in their niches that alter their interactions.

Vaccinium myrtillus is a key species forming shrub patches that colonize subalpine and alpine grasslands in the Pyrenees, where it grows close to the upper altitudinal limit of its distribution (Bolòs et al. 2005), experiencing low temperatures and short growing seasons.

97 Warmer temperatures could favour the growth and expansion of this species in the treeline ecotone, as has already been reported in a soil warming experiment in the Alps (Dawes et al. 
2011, Anadon-Rosell et al. 2014) and in other warming experiments in the Arctic tundra (Rinnan et al. 2009, Taulavuori et al. 2013). On the other hand, in line with the SGH, an amelioration of the environment could induce changes in the interaction between this species and its neighbours towards increased competition. Despite the numerous studies focusing on $V$. myrtillus in tundra ecosystems, to our knowledge the effects that warming may have on the interaction of this species with its neighbours have not been reported. Moreover, the previously mentioned experiments on $V$. myrtillus have mainly focused on its above-ground responses to warming, whereas below-ground responses have mostly been ignored.

At the treeline in the Central Pyrenees, V. myrtillus grows in pure patches (stands hereafter) or in mixed stands together with Vaccinium uliginosum ssp. microphyllum, or Rhododendron ferrugineum. The objective of this study was to investigate the above- (AG) and below-ground (BG) responses of $V$. myrtillus to four years of passive warming and whether warming induced changes in the interaction between $V$. myrtillus and its neighbouring shrub species. For this purpose we assessed $V$. myrtillus phenology, AG and BG biomass, carbon and nitrogen contents and isotopic signatures $\left(\delta^{13} \mathrm{C}\right.$ and $\left.\delta^{15} \mathrm{~N}\right)$, soil inorganic $\mathrm{N}$ pools (ammonium and nitrate) and nitrogen and carbon availability in the rhizosphere in different types of $V$. myrtillus stands subjected to warming treatments. We hypothesized that warming would (i) benefit $V$. myrtillus AG and BG growth, but that it would also (ii) increase the competition with its neighbouring species, which would be manifested as a positive $\mathrm{AG}$ and $\mathrm{BG}$ growth response of $V$. myrtillus to warming in pure stands but not in mixed stands, and also by a greater increase in the soil inorganic $\mathrm{N}$ pool under warming in pure stands than in mixed stands.

\section{Materials and methods}

\section{Study area}

The study site was located at Eth Corrau des Machos, in the buffer zone of the Aigüestortes and Estany de Sant Maurici National Park (Central Pyrenees, Catalonia, 31N 329, 472), on a N- 
facing $10-15^{\circ}$ steep slope at $2250 \mathrm{~m}$ a.s.l. The vegetation consisted of Festuca eskia Ramond ex DC. and Nardus stricta L. grasslands mixed with patches of dwarf shrub heath dominated by Vaccinium myrtillus L., Vaccinium uliginosum subsp. microphyllum (Lange) Tolm. and Rhododendron ferrugineum $\mathrm{L}$. The mean annual precipitation and mean annual temperature for the study period (2010-2013) were $1223.1 \mathrm{~mm}$ and $2.7^{\circ} \mathrm{C}$, respectively. The mean monthly precipitation and the mean temperature for the main months of the growing season (June-August) were $99.1 \mathrm{~mm}$ and $10.2^{\circ} \mathrm{C}$ (obtained from a meteorological station at a nearby location: La Bonaigua, $6.3 \mathrm{~km}$ away from the study site and at a similar altitude, run by the Meteorological Service of Catalonia).

\section{Experimental design}

In July 2010 we established 30 plots of $1.1 \mathrm{~m}^{2}$ combining a temperature and a coexistence treatment. In 15 plots we placed an open-top chamber (OTC) similar to the model used in the International Tundra Experiment (ITEX; Marion et al. 1997), which increased summer air temperature by $1.1{ }^{\circ} \mathrm{C}$ (measured by ibuttons placed at ground level); the other 15 plots served as controls for temperature. Within each temperature treatment, five plots were assigned to pure Vaccinium myrtillus stands (M stands), five to mixed stands of $V$. myrtillus and $V$. uligiosum subsp. microphyllum (hereafter $V$. uliginosum; U stands) and five to mixed stands of $V$. myrtillus and Rhododendron ferrugineum ( $\mathrm{R}$ stands). The distance between two plots ranged from one to a few metres $(<20 \mathrm{~m})$, always ensuring that the studied patches were independent.

\section{Phenology and community composition}

In 2011 we labelled six $V$. myrtillus ramets per plot, which we monitored during the growing seasons of 2011 and 2012 for a phenological survey. We recorded the following phenophases: winter state, bud swelling, bud bursting, leaf expansion, shoot elongation, vegetative state, leaf colour change, leaf shedding, leafless state and shoot winter colouring (brown-red coloration). We visited the plots $c a$. once a month starting after snowmelt until late Autumn, when ramets were leafless, and we recorded the presence of different phenophases in the six marked ramets. 
153 We assigned an ordinal numeric code to all phenophases and calculated the average numeric

154 code per plot as the average score of the six ramets at each visit.

155 Plant community composition within the study plots was first recorded in 2011, by

156 estimating the cover of the main plant groups in each plot, i.e. shrubs and grasses. This was re-

157 assessed in September 2013 before the end of the experiment (Supplementary material

158 Appendix 1 Table A1).

159

160

$A G$ and $B G$ biomass

161 On the 3rd September 2013 we harvested five $V$. myrtillus ramets per plot (not corresponding

162 with those phenologically surveyed) plus five $V$. uliginosum ramets in U plots. We also dug out

163 their rhizomes (down to $\mathrm{ca} .20 \mathrm{~cm}$ long) and the roots attached and collected six soil cores of 12

$164 \mathrm{~cm}$ length $\mathrm{x} 4 \mathrm{~cm}$ diameter in each plot. Soil samples were kept in sealed plastic bags in a cool

165 box until freezing in the lab. Two of these cores were used for BG biomass measurements at the

166 plot scale; two were used for measurements of soil nitrate and ammonia content; and the other

167 two were used for rhizosphere carbon and nitrogen content and isotope composition analyses.

168 The two soil cores obtained for the same purpose from each plot were pooled together, therefore

169 we had one composite soil sample per plot for each type of measurement.

170 Once in the lab, we measured the ramet height of both Vaccinium spp. and counted the

171 scars left by the buds in each ramet to estimate their age. Then, we separated leaves, new shoots

172 (i.e. shoots grown in 2013), rhizomes and roots, and dried them at $60{ }^{\circ} \mathrm{C}$ for 48 hours. Leaves

173 and new shoots were weighed for AG biomass measurements and subsequently used for

174 nitrogen and carbon content and isotope composition analyses. Rhizomes and roots were only

175 used for nitrogen and carbon content and isotope composition analyses, since BG biomass was

176 measured at the plot scale on material obtained from the soil cores. Since Vaccinium myrtillus is

177 a clonal plant with a long and complex rhizome network, we carried out BG biomass

178 measurements referring to a specific soil volume to make comparisons between warming

179 treatments and stand types possible. Soil cores for BG biomass measurements were sieved to 
separate rhizomes, coarse roots $(\geq 1 \mathrm{~mm}$ diameter) and fine roots $(<1 \mathrm{~mm}$ diameter). We dried

181

182

183

184

185

186

187

188

189

190

191

192

193

194

195 them in the oven at $60{ }^{\circ} \mathrm{C}$ for $48 \mathrm{~h}$ and weighed them for BG biomass analyses.

\section{Carbon and nitrogen content and isotope composition}

For the analyses of $\mathrm{C}$ and $\mathrm{N}$ content and isotope composition of leaves, new shoots, rhizomes and roots, we pooled together the material from all the harvested ramets of each plot for each Vaccinium spp. Then we ground the material and weighed $c a .1 \mathrm{mg}$ subsamples in small tin capsules. The nitrogen and carbon contents of samples were determined using an elemental analyzer (EA1108, Series 1; Carbo Erba Instrumentazione, Milan, Italy). The carbon and nitrogen isotope composition of samples were determined using a Flash 1112 Elemental Analyzer (Carbo Erba, Milan) coupled to an IRMS Delta C isotope ratio mass spectrometer through a Conflo III Interface (Thermo-Finnigan, Germany). The results of carbon isotope analyses are reported in per thousand (\%) on the relative $\delta$-scale as $\delta^{13} \mathrm{C}$, and refer to the international standard V-PDB (Vienna Pee Dee Belemnite) according to the following equation:

$$
\delta^{13} \mathrm{C}=\left(\frac{R_{\text {sample }}}{R_{\text {standard }}}\right)-1
$$

where $R$ is the ${ }^{13} \mathrm{C} /{ }^{12} \mathrm{C}$ ratio.

Carbon isotope discrimination $\left(\Delta^{13} \mathrm{C}\right)$ of shoot TOM (total organic matter) was calculated from $\delta_{\mathrm{a}}$ and $\delta_{\mathrm{p}}($ Farquhar et al. 1989) as:

$$
\Delta^{13} C=\frac{\delta_{a}-\delta_{p}}{\delta_{p}+1}
$$

where $a$ and $p$ refer to air and plant, respectively.

Nitrogen results were also expressed in $\delta$ notation $\left(\delta^{15} \mathrm{~N}\right)$ using international secondary standards of known ${ }^{15} \mathrm{~N} /{ }^{14} \mathrm{~N}$ ratios (IAEA $\mathrm{N}_{1}$ and IAEA $\mathrm{N}_{2}$ ammonium sulphate and IAEA $\mathrm{NO}_{3}$ potassium nitrate) relative to $\mathrm{N}_{2}$ in air: 
204

where $R$ is the ${ }^{15} \mathrm{~N} /{ }^{14} \mathrm{~N}$ ratio.

All EA-IRMS analyses were performed at the CCiT of the University of Barcelona. The $\delta^{13} \mathrm{C}$ of $\mathrm{CO}_{2}$ of the air and the $\delta^{15} \mathrm{~N}$ of the bulk soil were analysed in 2013 and were ca. $-10.91 \%$ and ca. $7.33 \%$, respectively.

\section{Soil inorganic nitrogen pool}

Nitrate concentrations were measured following the UV method described by Kaneko et al. (2010) by measuring the absorbance of $\mathrm{KCl}$ extracts from soils at $220 \mathrm{~nm}$ and $260 \mathrm{~nm}$ wavelengths. Soil ammonia concentrations were measured by the conversion of ammonium into the intense blue indophenol complex (IPC) using salicylate, following the methods used by Kempers and Kox (1989).

\section{Rhizospheric soil analyses}

We carefully selected rhizomes and roots from the two soil cores collected for rhizosphere analyses and separated the soil that was attached using a small paint brush. We ground the soil and weighed $c a .3 .5 \mathrm{mg}$ subsamples in small tin capsules and analysed its carbon and nitrogen content and isotope composition following the same procedure as for plant tissues.

\section{Statistical analyses}

We tested the effects of warming and stand type on V. myrtillus phenology, ramet height and AG biomass using linear mixed effects models fitted with the restricted maximum likelihood estimation method (REML). We included warming and stand type as fixed factors and plot as a random factor. We used the same models for $V$. uliginosum variables, but in this case we only used warming as a fixed factor. To test the effects of warming and stand type on the carbon and nitrogen content and isotope composition of the different AG and BG tissues, BG biomass, soil 
nitrate and ammonia contents and rhizosphere carbon and nitrogen content and isotope composition we used simple linear model functions. We included ramet age as a covariate in plant analyses when it was significant to account for possible age effects on our growth-related response variables. This included the models for $V$. myrtillus height and AG biomass (except for dry weight per shoot unit), plus the models for number of shoots and dry weight per shoot unit for $V$. uliginosum. We tested for significance with analysis of variance tests and we graphically evaluated the assumptions of normality and homoscedasticity of residuals (Zuur et al. 2009). We double-checked with Shapiro and Bartlett tests when the visual evaluation of graphs was difficult. We log-transformed data when necessary to satisfy these assumptions. Moreover, when homoscedasticity of residuals was not met, we used the varIdent structure (Zuur et al. 2009) to account for the heterogeneity of variances among factor levels. In $V$. uliginosum analyses, when both normality and homoscedasticity were not met, we used the non-parametric Wilcoxon test. We considered effects significant at $P<0.05$ and marginally significant at $0.05>$ $P<0.10$ to account for the relatively low replication. When we found significant differences between stand types, we carried out Tukey HSD post hoc tests to determine those factor levels that differed significantly. We performed all the analyses with R 3.1.2 (R Core Team 2015). For linear mixed effects models we used the nlme package (Pinheiro et al. 2008); for graphical evaluation of model assumptions we used the lattice package (Sarkar 2008); and for multiple comparisons we used the multcomp package on linear mixed effects models (Hothorn et al. 2008) and the agricolae package on simple linear models (de Mendiburu 2010).

\section{Results}

\section{Phenology}

Warming advanced early-season vegetative phenology through an earlier onset of bud burst and leaf expansion (see Supplementary material Appendix 1 Fig. A1). On the 21st May 2011 (day of year, DOY, 141), V. myrtillus ramets in unwarmed plots were at the bud swelling phase, 
whereas buds in ramets of warmed plots had already started bursting $\left(F_{1,24}=3.92, P=0.059\right)$. In 2012, V. myrtillus ramets in warmed plots were already expanding their leaves on the 14th June (DOY 166), whereas ramets in unwarmed plots were still in the bud burst phenophase $\left(F_{1,24}=\right.$ $6.59, P=0.017)$. Monitoring later in the season for both years did not show any other significant differences between warming treatments (see Supplementary material Appendix 1 Fig. A1 for visit dates). We only found significant differences between stand types (regardless of the warming treatment) in September 2011, when ramets in pure plots were already shedding the leaves whereas ramets in the other two stand types had just started changing their colour prior to leaf shedding $\left(F_{2,24}=9.31, P=0.001\right)$. This advancement in senescence in pure plots with respect to the other stand types was especially obvious in warmed plots (marginally significant interaction for coexistence $\mathrm{x}$ warming, $F_{2,24}=3.13, P=0.062$ ).

\section{Age and AG biomass of Vaccinium species}

Our age analyses confirmed that there were no differences in $V$. myrtillus ramet age between warming treatments $\left(F_{1,24}=0.16, P=0.696\right)$ nor between stand types $\left(F_{2,24}=1.89, P=0.173\right)$. Likewise $V$. uliginosum did not show differences in ramet age between warming treatments $\left(F_{1,6}\right.$ $=0.01, P=0.930)$.

After four years of warming, V. myrtillus ramets were $15 \%$ taller in warmed plots than in unwarmed plots. There were no differences in ramet height between stand types or an interaction between warming and stand type (Table 1). Similarly, there was no warming effect on $V$. uliginosum height $\left(F_{1,6}=0.07, P=0.802\right)$.

Vaccinium myrtillus leaf biomass per ramet did not differ between warming treatments (Table 1, Fig. 1a) but new shoot biomass was higher under warming than in control plots (Fig. 1b). The total above-ground biomass per ramet was also higher in warmed plots than in unwarmed plots (Table 1, Fig. 1c). There were no differences between stand types or a stand type $\mathrm{x}$ warming interaction for $V$. myrtillus AG biomass (Table 1). There were no differences between warming treatments in terms of $V$. uliginosum leaf biomass $\left(F_{1,6}=2.77, P=0.147\right)$, new shoot biomass $\left(F_{1,6}=0.04, P=0.849\right)$ or total AG biomass $\left(F_{1,6}=0.39, P=0.554\right.$, 
283

284

285

286

287

288

289

290

291

292

293

294

295

296

297

298

299

300

301

302

303

304

305

306

307

308

309

Supplementary material Appendix 1 Fig. A2), although we found contrasting effects of warming on the dry weight per shoot and the number of new shoots. Dry weight per shoot in $V$. uliginosum was higher inside the OTCs than in control plots $\left(F_{1,6}=6.42, P=0.044\right)$, whereas the number of new shoots was higher in ramets from unwarmed plots $\left(F_{1,6}=14.81, P=0.009\right)$.

Vaccinium myrtillus $B G$ biomass

There were no effects of warming on V. myrtillus BG biomass (Table 2, Fig. 2). We only found differences in rhizome and coarse root biomass between stand types. Plots with $R$. ferrugineum showed lower rhizome biomass per soil volume than in the other two stand types (Table 2, Fig. 2a). Plots with $V$. uliginosum showed marginally significant greater coarse root biomass than pure populations (Table 2, Fig. 2b). Fine root biomass did not differ between stand types (Table 2, Fig. 2c). We did not find any warming $x$ stand type interaction for any of the BG compartments analysed.

\section{Carbon and nitrogen content and isotope composition of $A G$ and $B G$ plant fractions}

Carbon concentration in $V$. myrtillus tissues was similar across warming treatments and stand types for leaves, shoots and roots. Rhizomes, however, had greater carbon content under warming than in control plots (Table 3, Fig. 3), which was not related to any rhizome biomass increase under warming (see above). Carbon concentration values of $V$. uliginosum new shoots, rhizomes and roots did not show any response to warming, but there was a marginally significant positive effect of warming on leaf C concentration (Table 4, Fig. 5).

The $\delta^{13} \mathrm{C}$ of $V$. myrtillus and $V$. uliginosum tissues did not differ between warming treatments (Fig. 3, 5) but we found significant differences in the $\delta^{13} \mathrm{C}$ of $V$. myrtillus tissues between stand types. Vaccinium myrtillus $\delta^{13} \mathrm{C}$ was lower in plots with $R$. ferrugineum than in the other two situations of coexistence for leaves (only marginally significant), shoots and rhizomes. There were no significant differences between stand types for the $\delta^{13} \mathrm{C}$ composition of roots (Table 3, Fig. 3), or any warming x stand type interaction. 

tissues, and only a very marginally significant interaction between warming and stand type in the $\mathrm{N}$ content of $V$. myrtillus rhizomes, which was higher in control plots than in warmed plots in U stands (Table 3, Fig. 4). However, we found significant differences between stand types. Leaf $\mathrm{N}$ content was higher in $\mathrm{R}$ stands than in $\mathrm{U}$ stands, but this was not the case for any of the other plant fractions. Leaf and shoot $\delta^{15} \mathrm{~N}$ values were higher in $\mathrm{M}$ stands than in the other two stand types, which is consistent with a previous study carried out in the area (Anadon-Rosell et al. in prep.). Finally, rhizome $\delta^{15} \mathrm{~N}$ values were also higher in $\mathrm{M}$ stands than in the other two stand types, but only significantly higher than in R stands (Table 3, Fig. 4). than in control plots, but this was associated with an increase in leaf $\mathrm{N}$ content under warming (although the latter was not significant). $\delta^{15} \mathrm{~N}$ values did not differ significantly between warming treatments (Table 4, Fig. 5).

\section{Soil inorganic $N$ pools and rhizosphere $C$ and $N$}

Soil nitrate content decreased by $36 \%$ in warmed plots compared with unwarmed plots $\left(F_{1,24}=\right.$ $5.87, P=0.023$, Fig. $6 \mathrm{a}$ ), but the ammonia content remained similar between warming treatments $(F=0.45, P=0.508$, Fig. $6 \mathrm{~b})$. As a consequence, the nitrate/ammonia ratio decreased by $27 \%$ under warming with respect to control conditions. There was no difference between stand types or any interaction between warming and stand type for any of the two $\mathrm{N}$ forms analysed. differed between stand types, as it was higher in $\mathrm{U}$ stands than in the other two $\left(F_{2,24}=7.99, P=\right.$ 0.002, Supplementary material Appendix 1 Fig. A3). Both rhizosphere soil C and N content were significantly higher in $\mathrm{U}$ stands than in $\mathrm{R}$ and $\mathrm{M}$ stands $\left(F_{2,24}=5.81, P=0.009\right.$ and $F_{2,24}=$ 3.64, $P=0.042$, respectively), but the difference in the $\mathrm{C}$ content was greater than the difference in $\mathrm{N}$ (data not shown). There was no significant warming $\mathrm{x}$ stand type interaction on the rhizosphere $\mathrm{C} / \mathrm{N}$ ratio $\left(F_{2,24}=0.89, P=0.422\right)$, but the high dispersion in the data could 
have masked possible differences between warming treatments in U stands. Neither warming nor stand type or their interaction had any effects on rhizospheric soil $\delta^{13} \mathrm{C}$ and $\delta^{15} \mathrm{~N}$ values $(P>$ $0.28)$.

\section{Discussion}

This study provides evidence that four years of passive warming did not lead to changes in the interaction between $V$. myrtillus and its neighbours at our treeline study site. Vaccinium myrtillus slightly benefitted from increased temperatures regardless of whether or not it was growing with a neighbouring species, or the identity of this neighbour.

According to the stress-gradient hypothesis (Bertness and Callaway 1994), we expected V. myrtillus to perform worse in warmed plots with neighbours than in pure stands due to increased competition caused by the amelioration of the environmental conditions with warming. However, our results indicate that, although the applied experimental warming of 1.1 ${ }^{\circ} \mathrm{C}$ was sufficient to improve $V$. myrtillus growth conditions, it was not sufficient to change the outcome of the interactions between $V$. myrtillus and its neighbouring shrubs. This contrasts with previous studies in which the interaction between plant species shifted when temperatures changed (both naturally and experimentally). Dormann et al. (2004) found that the interaction between the rush Luzula confusa and the deciduous shrub Salix polaris changed with warming in favour of S. polaris in Svalbard. In a removal experiment in Finse, Norway, Klanderud and Totland (2005) found that the removal of the neighbour species negatively affected Thalictrum, but not when the latter was inside an OTC, indicating that warming could affect the interaction between these species. Callaway et al. (2002) also reported evidence of a shift from facilitation at higher elevation sites to competition at lower elevation sites when removing neighbours of target individuals at 11 different mountain sites across the world. In addition, a study in seminatural grasslands across precipitation and temperature gradients in southern Norway found increased competitive interactions with increasing temperature (Olsen et al. 2016). Most of these studies consisted of removal experiments, which provide very important ecological and 
functional information about the community and species studied (see review by Díaz et al.

2003). However, despite their numerous advantages and outcomes, removal experiments cannot avoid the disturbance caused by the extraction of the desired species. In contrast, our approach was based on naturally established populations and species, and the avoidance of any disturbance caused by removing part of this natural assemblage allowed us to assess the natural response of our study species to warming. According to our results, species interactions can be less responsive to warming when studying them in their natural conditions and distribution. Vaccinium myrtillus, a species that is responsive to temperature change (Rinnan et al. 2009, Taulavuori et al. 2013, Anadon-Rosell et al. 2014, Dawes et al. 2015), showed positive growth responses to warming regardless of the neighbouring species. Its AG biomass was increased under warming, which could be the result of a longer growing period caused by the advancement of its early-vegetative phenology. A previous study on this same species in the Swiss Alps showed that its increase in growth after six years of soil warming with heating cables was not related to a longer growing period (Anadon-Rosell et al. 2014). The aboveground phenology of ramets could be more affected by warming through OTCs than by soil warming, since air temperature at canopy level may be higher in OTCs than in plots with warmed soil. However, it could also be that other factors related to warming but not directly linked to a longer growing season influenced $V$. myrtillus growth in our study, such as direct warming effects on photosynthetic rates (Heskel et al. 2013, Fu et al. 2015) or higher N uptake rates with increased temperatures, which would be supported by the lower soil nitrate values found at our study plots under warming. Although there was no increase in the nitrogen content of our study ramets with warming that would support the notion of increased $\mathrm{N}$ uptake rates, the $\mathrm{N}$ increase could be diluted by the increased growth under warming. In fact, a study in the Swedish Lapland by Hartley et al. (1999) found no response of $V$. myrtillus and $V$. uliginosum leaf $\mathrm{N}$ concentrations to warming despite increased mineralization rates, which the authors attributed to an increase in $\mathrm{N}$ in their study plants through increased biomass. 
growth. Moreover, BG interactions between our study species did not change with warming

either. Although OTCs mainly increase ground-level and air temperature, they have been found to slightly increase soil temperature at $5 \mathrm{~cm}$ depth (Hollister et al. 2006) and even at $10 \mathrm{~cm}$ in steppe ecosystems in Northern Mongolia (Sharkhuu et al. 2013). Hollister and Flaherty (2010) found a BG biomass increase in Salix rotundifolia at a tundra site in Alaska after 3-4 years of warming with OTCs, but Shaver et al. (1998) found no BG biomass increase after 6-9 years of passive warming in another Alaskan wet sedge tundra, indicating contrasting BG responses to warming depending on the study site and community composition. Vaccinium myrtillus can expand its rhizomes several metres below-ground (Flower-Ellis, 1971); therefore our warming treatment might not have reached a large enough area to capture the potential response of a whole functional unit to warming, or a possible transfer of assimilates from AG parts might have been diluted by the complex BG network of this species.

Vaccinium uliginosum has been shown to be less plastic in response to warming than $V$. myrtillus (Richardson et al. 2002, Kudo and Suzuki 2003, Anadon-Rosell et al. 2014). This can be attributed to the better adaptation of $V$. myrtillus to warmer temperatures, as shown by its lower altitudinal range (Bolòs et al. 2005). Although the dry weight of new individual shoots of V. uliginosum increased with warming, the number of shoots decreased, probably as a trade-off, which led to an overall lack of AG biomass response to warming in this species. In fact, only the leaf carbon content of $V$. uliginosum increased with warming, but the statistical significance was marginal, and was not accompanied by any other changes in the performance of this shrub. Our study provides evidence that although $V$. myrtillus is more responsive to warming than $V$. uliginosum, when they coexist $V$. myrtillus does not benefit more from warming than when it grows in pure stands. unwarmed plots when coexisting with $V$. uliginosum indicates an increase in competition for $\mathrm{N}$ with warming. In fact, competition for $\mathrm{N}$ in mixed stands of these two species under natural conditions was found in a previous study at the same site (Anadon-Rosell et al. in prep.). The 
421 the idea of the occurrence of natural competition for $\mathrm{N}$ without warming, which would be

422 increased with the higher temperatures inside the OTC. A study in the Swiss Alps found a

423 positive response of warming in $V$. gaultherioides (synonym of $V$. uliginosum subsp.

424 microphyllum) leaf $\mathrm{N}$ content but only a short-term positive response in $V$. myrtillus (Dawes et

425 al. 2011). On the other hand, contrasting effects were found in an experiment in the Swedish

426 Lapland, where $V$. myrtillus showed a positive response in terms of leaf $\mathrm{N}$ content to warming

427 whereas $V$. uliginosum responded negatively (Richardson et al. 2002). However, none of these

428 studies tested the effects of warming on these species' interactions and the ultimate effects they

429 would have on their performance. Our study demonstrates that although warming increased the

430 competition for $\mathrm{N}$ between $V$. myrtillus and $V$. uliginosum, this ultimately did not outbalance the

431 positive growth response of $V$. myrtillus to warming.

432 A meta-analysis of experimental warming effects on $\mathrm{N}$ pools in terrestrial ecosystems

433 based on 51 studies showed that warming increased $\mathrm{N}$ mineralization rates and $\mathrm{N}$ pools across

434 different ecosystem types (Bai et al. 2013). However, in our experiment soil nitrate decreased

435 with warming (regardless of the stand type). This could be explained by greater nitrate uptake

436 rates promoted by increased temperatures, since temperature has been proven to be a modulator

437 of plant $\mathrm{N}$ assimilation in previous studies (Laine et al. 1994, Volder et al. 2000). The lack of an

438 increase in the $\mathrm{N}$ concentration of plant tissues could be due to a dilution effect caused by the

439 greater biomass or to increased nitrate assimilation by other species (especially grasses, due to

440 their abundance), which were not assessed in this study. Another explanation for the reduced

441 nitrate concentrations in the OTCs could be earlier consumption of nitrate through an advanced

442 root phenology promoted by warming (Sullivan and Welker 2005, Nord and Lynch 2009). A

443 study by Rinnan et al. (2009) in a tundra heath dominated by V. myrtillus, V. vitis-idaea and

444 Empetrum nigrum in southwestern Finland found no increase in soil $\mathrm{N}$ content with warming

445 either, but there was a decrease in the soil $\mathrm{NH}_{4}{ }^{+}$concentration inside the OTCs. The authors

446 argued that this reduction could reflect the increased efficiency of $\mathrm{N}$ uptake with warming. The

447 differing responses in the $\mathrm{N}$ form between that study and ours might reflect the preferential use 
of a specific $\mathrm{N}$ form at different sites with different community composition, or a greater

449

450

451

452

453

454

455

456

457

458

availability of nitrate than ammonia at our study site.

In conclusion, four years of experimental warming had no effect on the interaction between $V$. myrtillus and $V$. uliginosum or R. ferrugineum. Vaccinium myrtillus showed a positive AG growth response to warming regardless of the neighbouring species, but no BG responses were found. Although warming seemed to increase the competition for $\mathrm{N}$ between the two Vaccinium species, their overall performance was not affected. This study shows that species' interactions are not altered by warming at this treeline site and, thus, the performance of these populations will probably not change due to mild warming in the near future.

\section{Acknowledgements}

We thank Clara Borrull, Noelia Seguer, Estela Illa, Oriol Grau, Victoria Lafuente, Elena Lahoz and Santiago Pérez for their help in the field and laboratory assistance. We are grateful to CCiT of the University of Barcelona for the use of their facilities and their technical assistance. This project was partly funded by Conselh Generau d'Aran and the project ARBALMONT /7862012 (Organismo Autónomo Parques Nacionales, Ministerio de Agricultura, Alimentación y Medio Ambiente, Spain). AAR was funded by an FPU grant (Ministerio de Educación, Cultura y Deporte, Spain) and SP was funded by a Ramón y Cajal fellowship (RYC-2013-14164, Ministerio de Economía y Competitividad, Spain).

\section{References}

Anadon-Rosell, A. et al. 2014. Growth and phenology of three dwarf shrub species in a six-year soil warming experiment at the alpine treeline. - Plos One doi: 10.1371/journal.pone.0100577.

Bai, E. et al. 2013. A meta-analysis of experimental warming effects on terrestrial nitrogen pools and dynamics. - New Phytol. 199: 441-451. 
Bardgett, R.D. and Wardle, D.A. 2010. Aboveground-belowground linkages. Biotic interactions, ecosystem processes, and global change. - Oxford Series in Ecology and Evolution.

Bertness, M. D. and Callaway, R. 1994. Positive interactions in communities. - Trends Ecol. Evol. 9: 187-191.

Bolòs, O. et al. 2005. Flora Manual dels Països Catalans. 3rd ed. rev. and ext. - Ed. Pòrtic SA.

Callaway, R. M. and Walker, L. R. 1997. Competition and facilitation: a synthetic approach to interactions in plant communities. - Ecology 78: 1958-1965.

Callaway, R. M. et al. 2002. Positive interactions among alpine plants increase with stress. Nature 417: 844-848.

Choler, P. et al. 2001. Facilitation and competition on gradients in alpine plant communities. Ecology 82: 3295-3308.

Collins, M. et al. 2013. Long-term climate change: projections, commitments and irreversibility. In: Stocker, T.F. et al. (eds.). Climate Change 2013: The physical science basis. Contribution of Working Group I to the Fifth Assessment Report of the Intergovernmental Panel on Climate Change. - Cambridge University Press, pp. 10291136.

Cornelissen, J. H. C. et al. 2007. Global negative vegetation feedback to climate warming responses of leaf litter decomposition rates in cold biomes. - Ecol. Lett. 10: 619-627.

Cornelissen, J. H. C. et al. 2014. Plant traits and ecosystem effects of clonality: a new research agenda. - Ann. Bot. doi:10.1093/aob/mcu113.

D'Odorico, P. et al. 2013. Vegetation-microclimate feedbacks in woodland-grassland ecotones. - Glob. Ecol. Biogeogr. 22: 364-379.

Dawes, M. A. et al. 2011. Growth and community responses of alpine dwarf shrubs to in situ $\mathrm{CO}_{2}$ enrichment and soil warming. - New Phytol. 191: 806-818.

Dawes, M. A. et al. 2015. Soil warming and $\mathrm{CO}_{2}$ enrichment induce biomass shifts in alpine tree line vegetation. - Glob. Change Biol. 21: 2005-2021. 
Díaz, S. et al. 2003. Functional diversity revealed by removal experiments. - Trends Ecol. Evol. 18: $140-146$.

Dormann, C. F. et al. 2004. Neighbour identity modifies effects of elevated temperature on plant performance in the High Arctic. - Glob. Change Biol. 10: 1587-1598.

Dullinger, S. et al. 2003. Patterns of shrub invasion into high mountain grasslands of the Northern Calcareous Alps, Austria. - Arct. Antarct. Alp. Res. 35: 434-441.

Farquhar, G.D. et al. 1989. Carbon isotope discrimination and photosynthesis. - Annu. Rev. Plant Phys. 40: 503-537.

Flower-Ellis, J.G.K. 1971. Age, structure and dynamics in stands of bilberry (Vaccinium myrtillus L.) Department of Forest Ecology and Forest Soils. Research Note 9. Royal College of Forestry, Stockholm, Sweden.

Fu, G. et al. 2015. A meta-analysis of the effects of experimental warming on plant physiology and growth on the Tibetan Plateau. - J. Plant Growth Regul. 34: 57-65.

Hartley, A. E. et al. 1999. Plant performance and soil nitrogen mineralization in response to simulated climate change in subarctic dwarf shrub heath. - Oikos 86: 331-343.

Heskel, M. et al. 2013. Differential physiological responses to environmental change promote woody shrub expansion. - Ecol. Evol. 3: 1149-1162.

Hobbie, S. E. 1996. Temperature and plant species control over litter decomposition in Alaskan tundra. - Ecol. Monogr. 66: 503-522.

Hollister, R. D. and Flaherty, K. J. 2010. Above- and below-ground plant biomass response to experimental warming in northern Alaska. - Appl. Veg. Sci. 13: 378-387.

Hollister, R. D. et al. 2006. Soil thaw and temperature response to air warming varies by plant community: results from an open-top chamber experiment in northern Alaska. - Arct. Antarct. Alp. Res. 38: 206-215.

Hothorn, T. et al. 2008. Simultaneous inference in general parametric models. - Biometrical J. 50: $346-363$. 
Kaneko, S. et al. 2010. A simple method for the determination of nitrate in potassium chloride extracts from forest soils. In: Gilkes, R.J. et al. (eds.). Proceedings of the 19th World Congress of Soil Science: Soil solutions for a changing world. pp. 4-7.

Kempers AJ, Kok CJ. 1989. Re-examination of the determination of ammonium as the indophenol blue complex using salicylate. Anal. Chim. Acta 221: 147-155.

Klanderud, K. 2005. Climate change effects on species interactions in an alpine plant community. - J. Ecol. 93: 127-137.

Klanderud, K. 2008. Species-specific responses of an alpine plant community under simulated environmental change. - J. Veg. Sci. 19: 363-372.

Klanderud, K. and Totland, Ø. 2005. The relative importance of neighbours and abiotic environmental conditions for population dynamic parameters of two alpine plant species. - J. Ecol. 93: 493-501.

Körner, C. 2003. Alpine plant life: functional plant ecology of high mountain ecosystems. 2n ed. - Springer.

Kudo, G. and Suzuki, S. 2003. Warming effects on growth, production, and vegetation structure of alpine shrubs: a five-year experiment in northern Japan. - Oecologia 135: 280-287.

Laine, P. et al. 1994. Effects of low temperature on nitrate uptake, and xylem and phloem flows of nitrogen, in Secale cereale L. and Brassica napus L. - New Phytol. 127: 675-683.

Little, C. J. et al. 2015. Community and species-specific responses to simulated global change in two subarctic-alpine plant communities. - Ecosphere 6:227 doi 10.1890/ES14-00427.1.

Marion, G. M. et al. 1997. Open-top designs for manipulating field temperature in high-latitude ecosystems. - Glob. Change Biol. 3: 20-32.

de Mendiburu, F. 2010. agricolae: Statistical procedures for agricultural research. R package version 1.0-9. URL http://CRAN.R-project.org/package=agricolae.

Myers-Smith, I. H. et al. 2011. Shrub expansion in tundra ecosystems: dynamics, impacts and research priorities. - Environ. Res. Lett. 6 doi: 10.1088/1748-9326/6/4/045509.

Nord, E. A. and Lynch, J. P. 2009. Plant phenology: a critical controller of soil resource acquisition. - J. Exp. Bot. 60: 1927-1937. 
Olsen, S. L. et al. 2016. From facilitation to competition: temperature-driven shift in dominant plant interactions affects population dynamics in seminatural grasslands. - Glob. Change Biol. 22: 1915-1926.

Pinheiro, J. et al. 2008. NLME: linear and nonlinear mixed effects models. R package version $3.1-89$.

Pornon, A. et al. 2007. Complementarity in mineral nitrogen use among dominant plant species in a subalpine community. - Am. J. Bot. 94: 1778-1785.

Pugnaire, F. I. et al. 2015. No evidence of facilitation collapse in the Tibetan plateau. - J. Veg. Sci. 26: 233-242.

R Core Team. 2015. R: A language and environment for statistical computing. R Foundation for Statistical Computing, Vienna, Austria. ISBN 3-900051-07-0, URL http://www.Rproject.org/

Richardson, S. J. et al. 2002. How do nutrients and warming impact on plant communities and their insect herbivores? A 9-year study from a sub-Arctic heath. - J. Ecol. 90: 544-556.

Rinnan, R. et al. 2009. Responses of vegetation and soil microbial communities to warming and simulated herbivory in a subarctic heath. - J. Ecol. 97: 788-800.

Ropars, P. and Boudreau, S. 2012. Shrub expansion at the forest-tundra ecotone: Spatial heterogeneity linked to local topography. - Environ. Res. Lett. 7 doi 10.1088/17489326/7/1/015501.

Rundqvist, S. et al. 2011. Tree and shrub expansion over the past 34 years at the tree-line near Abisko, Sweden. - Ambio 40: 683-692.

Sarkar, D. 2008. Lattice: Multivariate data visualization with R. Springer, New York.

Sharkhuu, A. et al. 2013. Effects of open-top passive warming chambers on soil respiration in the semi-arid steppe to taiga forest transition zone in Northern Mongolia. Biogeochemistry 115: 333-348.

Shaver, G. R. et al. 1998. Biomass and $\mathrm{CO}_{2}$ flux in wet sedge tundras: responses to nutrients, temperature, and light. - Ecol. Monogr. 68: 75-97. 
583 Shevtsova, A. et al. 1997. Growth response of subarctic dwarf shrubs, Empetrum nigrum and 584 Vaccinium vitis-idaea, to manipulated environmental conditions and species removal. $585 \quad$ Oikos 78: 440-458.

586 Sullivan, P. F. and Welker, J. M. 2005. Warming chambers stimulate early season growth of an 587 Arctic sedge: results of a minirhizotron field study. - Oecologia 142: 616-626.

588 Taulavuori, K. et al. 2013. Experimental studies on Vaccinium myrtillus and Vaccinium vitis589 idaea in relation to air pollution and global change at northern high latitudes: a review. $590 \quad$ Environ. Exp. Bot. 87: 191-196.

591 Volder, A. et al. 2000. The influence of temperature and nitrogen source on growth and nitrogen 592 uptake of two polar-desert species, Saxifraga caespitosa and Cerastium alpinum. - Plant $593 \quad$ Soil 227: 139-148.

594 Wheeler, J. A. et al. 2015. With a little help from my friends: community facilitation increases 595 performance in the dwarf shrub Salix herbacea. - Basic Appl. Ecol. 16: $202-209$.

596 Yang, Y. et al. 2015. Plant community responses to five years of simulated climate warming in 597 an alpine fen of the Qinghai-Tibetan Plateau. - Plant Ecol. Divers. 8: 211-218.

598 Zuur, A.F. et al. 2009. Mixed effects models and extensions in ecology with R. Springer, New $599 \quad$ York.

600

601 
603 Table 1. Results of ANOVA for effects of warming and stand type on Vaccinium myrtillus

604 above-ground (AG) growth and biomass parameters at the ramet scale. Significant $(P>0.05)$

605 and marginally significant $(0.01>P>0.05)$ effects are in bold.

\begin{tabular}{|c|c|c|c|c|}
\hline AG Variable & Factor/covariable & $\mathrm{df}$ & $F$ & $P$ \\
\hline \multirow[t]{4}{*}{ Height } & Age & 1,118 & 26.47 & $<0.001$ \\
\hline & Warming & 1,24 & 5.33 & 0.030 \\
\hline & Stand type & 2,24 & 1.89 & 0.173 \\
\hline & Stand type $\mathrm{x}$ warming & 2,24 & 0.16 & 0.857 \\
\hline \multirow[t]{4}{*}{ Leaf biomass } & Age & 1,118 & 12.00 & 0.001 \\
\hline & Warming & 1,24 & 2.38 & 0.136 \\
\hline & Stand type & 2,24 & 1.49 & 0.246 \\
\hline & Stand type $\mathrm{x}$ warming & 2,24 & 1.20 & 0.320 \\
\hline \multirow[t]{4}{*}{ New shoots biomass } & Age & 1,118 & 8.68 & 0.004 \\
\hline & Warming & 1,24 & 5.02 & 0.035 \\
\hline & Stand type & 2,24 & 1.38 & 0.271 \\
\hline & Stand type $\mathrm{x}$ warming & 2,24 & 0.37 & 0.693 \\
\hline \multirow[t]{4}{*}{ Total AG biomass } & Age & 1,118 & 32.41 & $<0.001$ \\
\hline & Warming & 1,24 & 4.74 & 0.040 \\
\hline & Stand type & 2,24 & 1.77 & 0.193 \\
\hline & Stand type $\mathrm{x}$ warming & 2,24 & 0.16 & 0.857 \\
\hline \multirow[t]{4}{*}{ No. of shoots } & Age & 1,114 & 23.45 & $<0.001$ \\
\hline & Warming & 1,23 & 0.26 & 0.613 \\
\hline & Stand type & 2,23 & 0.84 & 0.443 \\
\hline & Stand type $\mathrm{x}$ warming & 2,23 & 0.83 & 0.450 \\
\hline \multirow[t]{4}{*}{ Dry weight/shoot } & Age & - & - & - \\
\hline & Warming & 1,23 & 3.85 & 0.062 \\
\hline & Stand type & 2,23 & 2.59 & 0.100 \\
\hline & Stand type $\mathrm{x}$ warming & 2,23 & 0.55 & 0.584 \\
\hline
\end{tabular}

606 
609 biomass. Significant $(P>0.05)$ and marginally significant $(0.01>P>0.05)$ effects are in bold.

\begin{tabular}{llccc}
\hline BG Variable & Factor & df & $F$ & $P$ \\
\hline Rhizome biomass & Warming & 1,24 & 2.98 & 0.100 \\
& Stand type & 2,24 & 6.93 & $\mathbf{0 . 0 0 4}$ \\
& Stand type x warming & 2,24 & 0.03 & 0.970 \\
& & & & \\
Coarse roots biomass & Warming & 1,19 & 0.91 & 0.352 \\
& Stand type & 2,19 & 3.04 & $\mathbf{0 . 0 7 1}$ \\
& Stand type x warming & 2,19 & 0.30 & 0.745 \\
Fine roots biomass & & & & \\
& Warming & 1,24 & 0.88 & 0.358 \\
& Stand type & 2,24 & 0.41 & 0.667 \\
& Stand type x warming & 2,24 & 0.57 & 0.575
\end{tabular}

610

611 
612 Table 3 . Results of ANOVA for effects of warming (W) and stand type (ST) on the C and N

613 concentration and isotope composition $\left(\delta^{13} \mathrm{C}, \delta^{15} \mathrm{~N}\right)$ of Vaccinium myrtillus leaves, new shoots,

614 rhizomes and roots. $F$-values and $P$-values (in parentheses) are given. Significant $(P>0.05)$ and

615 marginally significant $(0.01>P>0.05)$ effects are in bold. Between-groups degrees of freedom

616 were 1 for W, 2 for ST and 2 for ST x W. Within-groups degrees of freedom were 24, except for

$617 \operatorname{root} \mathrm{N}$ concentration and rhizome $\mathrm{C}$ and $\mathrm{N}$ concentration (22) and root $\delta^{15} \mathrm{~N}(23)$.

\begin{tabular}{|c|c|c|c|c|}
\hline Fraction & Variable & W & ST & $\mathrm{W} \times \mathrm{ST}$ \\
\hline \multirow[t]{4}{*}{ Leaves } & $\mathrm{C}$ concentration & $0.93(0.344)$ & $1.51(0.242)$ & $1.57(0.228)$ \\
\hline & $\mathrm{N}$ concentration & $0.02(0.884)$ & $4.93(\mathbf{0 . 0 1 6})$ & $0.07(0.931)$ \\
\hline & $\delta^{13} \mathrm{C}$ & $0.90(0.352)$ & $2.72(\mathbf{0 . 0 8 6})$ & $0.85(0.441)$ \\
\hline & $\delta^{15} \mathrm{~N}$ & $0.08(0.780)$ & $10.28(\mathbf{0 . 0 0 1})$ & $0.04(0.960)$ \\
\hline \multirow[t]{4}{*}{ New shoots } & $\mathrm{C}$ concentration & $1.68(0.207)$ & $0.94(0.404)$ & $0.94(0.404)$ \\
\hline & $\mathrm{N}$ concentration & $0.07(0.793)$ & $0.63(0.540)$ & $0.77(0.472)$ \\
\hline & $\delta^{13} \mathrm{C}$ & $0.07(0.794)$ & $8.16(\mathbf{0 . 0 0 2})$ & $1.85(0.179)$ \\
\hline & $\delta^{15} \mathrm{~N}$ & $0.33(0.571)$ & $9.39(\mathbf{0 . 0 0 1})$ & $0.00(1.000)$ \\
\hline \multirow[t]{4}{*}{ Rhizomes } & $\mathrm{C}$ concentration & $5.71(\mathbf{0 . 0 2 6})$ & $0.33(0.723)$ & $0.7(0.509)$ \\
\hline & $\mathrm{N}$ concentration & $0.05(0.829)$ & $0.46(0.637)$ & 2.57 (0.099) \\
\hline & $\delta^{13} \mathrm{C}$ & $0.42(0.522)$ & $8.78(\mathbf{0 . 0 0 1})$ & $0.03(0.972)$ \\
\hline & $\delta^{15} \mathrm{~N}$ & $0.02(0.884)$ & $6.53(\mathbf{0 . 0 0 5})$ & $0.08(0.921)$ \\
\hline \multirow[t]{4}{*}{ Roots } & $\mathrm{C}$ concentration & $0.21(0.653)$ & $0.43(0.656)$ & $0.56(0.578)$ \\
\hline & $\mathrm{N}$ concentration & $1.69(0.207)$ & $0.62(0.545)$ & $1.19(0.323)$ \\
\hline & $\delta^{13} \mathrm{C}$ & $1.59(0.218)$ & $0.15(0.860)$ & $2.53(0.101)$ \\
\hline & $\delta^{15} \mathrm{~N}$ & $0.21(0.650)$ & $2.04(0.153)$ & $0.19(0.826)$ \\
\hline
\end{tabular}

618

619 
620 Table 4. Results of ANOVA or Wilcoxon tests for the effects of warming on the $\mathrm{C}$ and $\mathrm{N}$

621 concentration and isotope composition $\left(\delta^{13} \mathrm{C}, \delta^{15} \mathrm{~N}\right)$ of Vaccinium uliginosum leaves, new

622 shoots, rhizomes and roots. Significant $(P>0.05)$ and marginally significant $(0.01>P>0.05)$

623 effects are in bold.

\begin{tabular}{lllll}
\hline Fraction & Parameter & $\mathrm{df}$ & \multicolumn{1}{c}{$F / W$} & $P$ \\
\hline Leaves & $\mathrm{C}$ concentration & 1,6 & 3.89 & $\mathbf{0 . 0 9 6}$ \\
& $\mathrm{N}$ concentration & 1,6 & 2.57 & 0.160 \\
& $\delta^{13} \mathrm{C}$ & 1,6 & 0.01 & 0.934 \\
& $\delta^{15} \mathrm{~N}$ & - & $W=6$ & 0.686 \\
New shoots & $\mathrm{C}$ concentration & - & $W=6$ & 0.686 \\
& $\mathrm{~N}$ concentration & 1,6 & 13.91 & $\mathbf{0 . 0 1 0}$ \\
& $\delta^{13} \mathrm{C}$ & 1,6 & 0.03 & 0.871 \\
& $\delta^{15} \mathrm{~N}$ & 1,6 & 0.35 & 0.575 \\
Rhizomes & $\mathrm{C}$ concentration & 1,6 & 0.99 & 0.357 \\
& $\mathrm{~N}$ concentration & - & $W=8$ & 1.000 \\
& $\delta^{13} \mathrm{C}$ & - & $W=8$ & 1.000 \\
& $\delta^{15} \mathrm{~N}$ & - & $W=8$ & 1.000 \\
& $\mathrm{C}$ concentration & 1,6 & 0.00 & 0.997 \\
& $\mathrm{~N}$ concentration & 1,6 & 0.93 & 0.373 \\
& $\delta^{13} \mathrm{C}$ & 1,6 & 1.08 & 0.339 \\
& $\delta^{15} \mathrm{~N}$ & 1,6 & 3.86 & 0.097 \\
& & & &
\end{tabular}

624

625 
627 Figure 1. Vaccinium myrtillus AG biomass in different stand types (ST) and warming treatments

628 in September $2013\left(\mathrm{~W} ; n=5\right.$, means $+1 \mathrm{SE}$ are shown). Asterisks $\left({ }^{* *}\right)$ show significant

629 differences at $0.05>P>0.01$. M: $V$. myrtillus pure stands; R: $V$. myrtillus mixed with $R$.

630 ferrugineum stands; U: V. myrtillus mixed with V. uliginosum stands. 
632 Figure 2. BG biomass per soil volume at the plot scale in different stand types (ST) and 633 warming treatments in September 2013 (W; $n=5$, means $+1 \mathrm{SE}$ are shown). Asterisks show 634 significant differences $(*$ marginally significant differences at $0.1>P>0.05 ; * *$ significant 635 differences at $0.05>P>0.01$; *** significant differences at $P<0.01)$. M: V. myrtillus pure 636 stands; R: V. myrtillus mixed with R. ferrugineum stands; U: V. myrtillus mixed with $V$. 637 uliginosum stands. 
639 Figure 3. Carbon concentration and $\delta^{13} \mathrm{C}$ of $V$. myrtillus tissues in different stand types (ST) and 640 warming treatments in September $2013(\mathrm{~W} ; n=5$, mean +1 SE for concentrations and mean - 1 641 SE for isotope compositions are shown). Asterisks show significant differences (* marginally

642 significant differences at $0.1>P>0.05 ; * *$ significant differences at $0.05>P>0.01 ; * * *$

643 significant differences at $P<0.01)$. M: $V$. myrtillus pure stands; R: $V$. myrtillus mixed with $R$.

644 ferrugineum stands; U: V. myrtillus mixed with V. uliginosum stands. 
646 Figure 4. Nitrogen concentration and $\delta^{15} \mathrm{~N}$ of $V$. myrtillus tissues in different stand types (ST)

647 and warming treatments in September $2013(\mathrm{~W} ; n=5$, mean +1 SE for concentrations and

648 mean - 1 SE for isotope compositions are shown). For $\mathrm{N}$ concentration of rhizomes and roots

649 see the righthand Y-axis scale. Asterisks show significant differences (* marginally significant

650 differences $0.1>P>0.05 ; * * *$ significant differences at $P<0.01$ ). M: $V$. myrtillus pure stands;

651 R: V. myrtillus mixed with R. ferrugineum stands; U: V. myrtillus mixed with $V$. uliginosum

652 stands.

653 
654 Figure 5. Carbon and nitrogen concentrations and $\delta^{13} \mathrm{C}$ and $\delta^{15} \mathrm{~N}$ of $V$. uliginosum tissues under 655 different warming treatments in September $2013(\mathrm{~W} ; n=4$, mean +1 SE for concentrations and 656 mean - 1 SE for isotope compositions are shown). Asterisks (***) show significant differences 657 between warming treatments at $P<0.01$.

658 
659 Figure 6. Soil nitrate and ammonia content in our study plots in different stand types (ST) and

660 warming treatments in September 2013 (W; $n=5$, means +1 SE are shown). Asterisks (***)

661 show significant differences at $P<0.01$. M: $V$. myrtillus pure stands; R: $V$. myrtillus mixed with

662 R. ferrugineum stands; U: V. myrtillus mixed with $V$. uliginosum stands. 


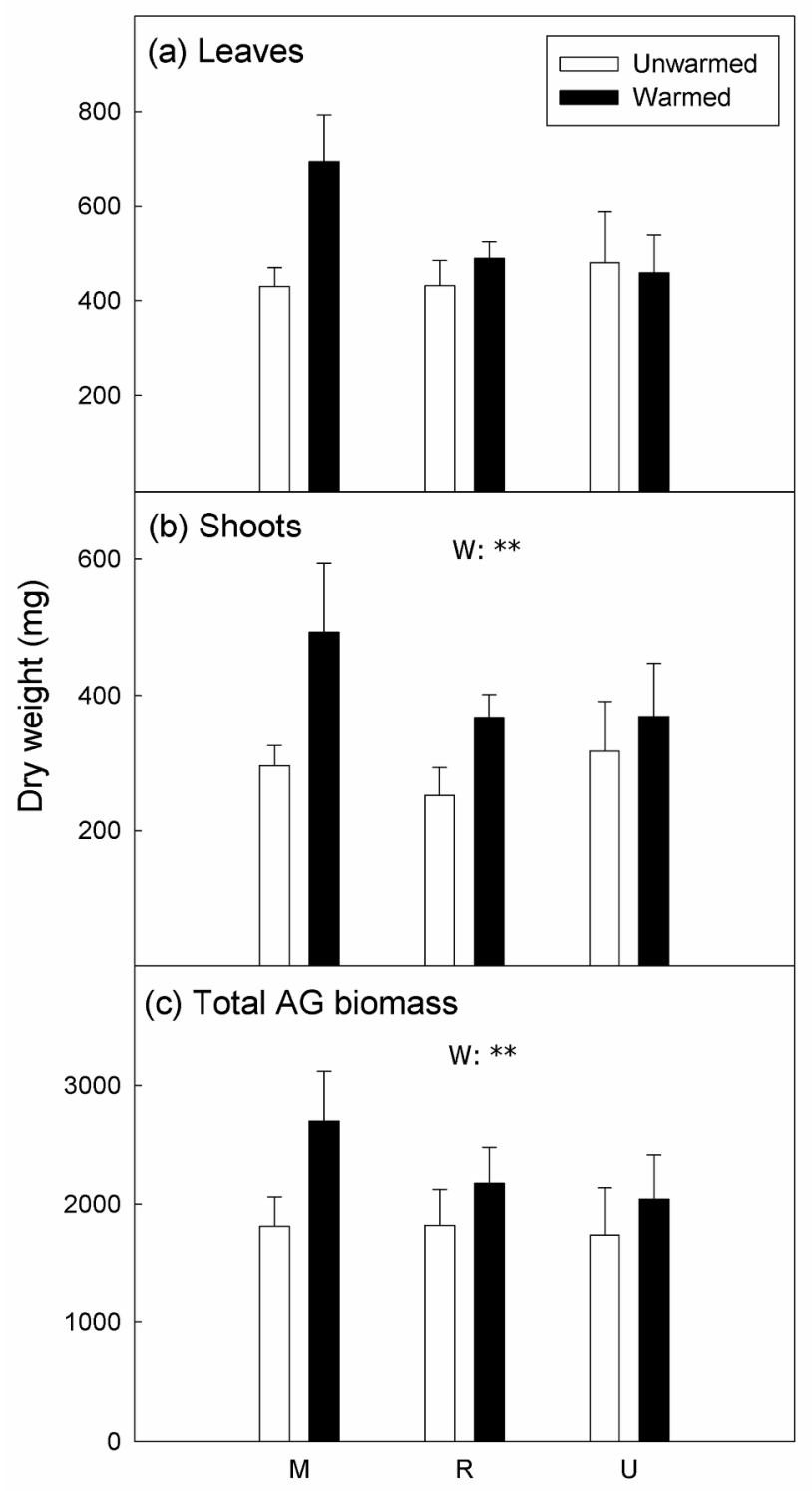

Figure 1. Vaccinium myrtillus AG biomass in different stand types (ST) and warming treatments in September 2013 (W; $n=5$, means +1 SE are shown). Asterisks $\left({ }^{* *}\right)$ show significant differences at $0.05>$ $\mathrm{P}>0.01$. M: V. myrtillus pure stands; R: V. myrtillus mixed with R. ferrugineum stands; U: $V$. myrtillus mixed with $V$. uliginosum stands. $150 \times 283 \mathrm{~mm}(300 \times 300 \mathrm{DPI})$ 


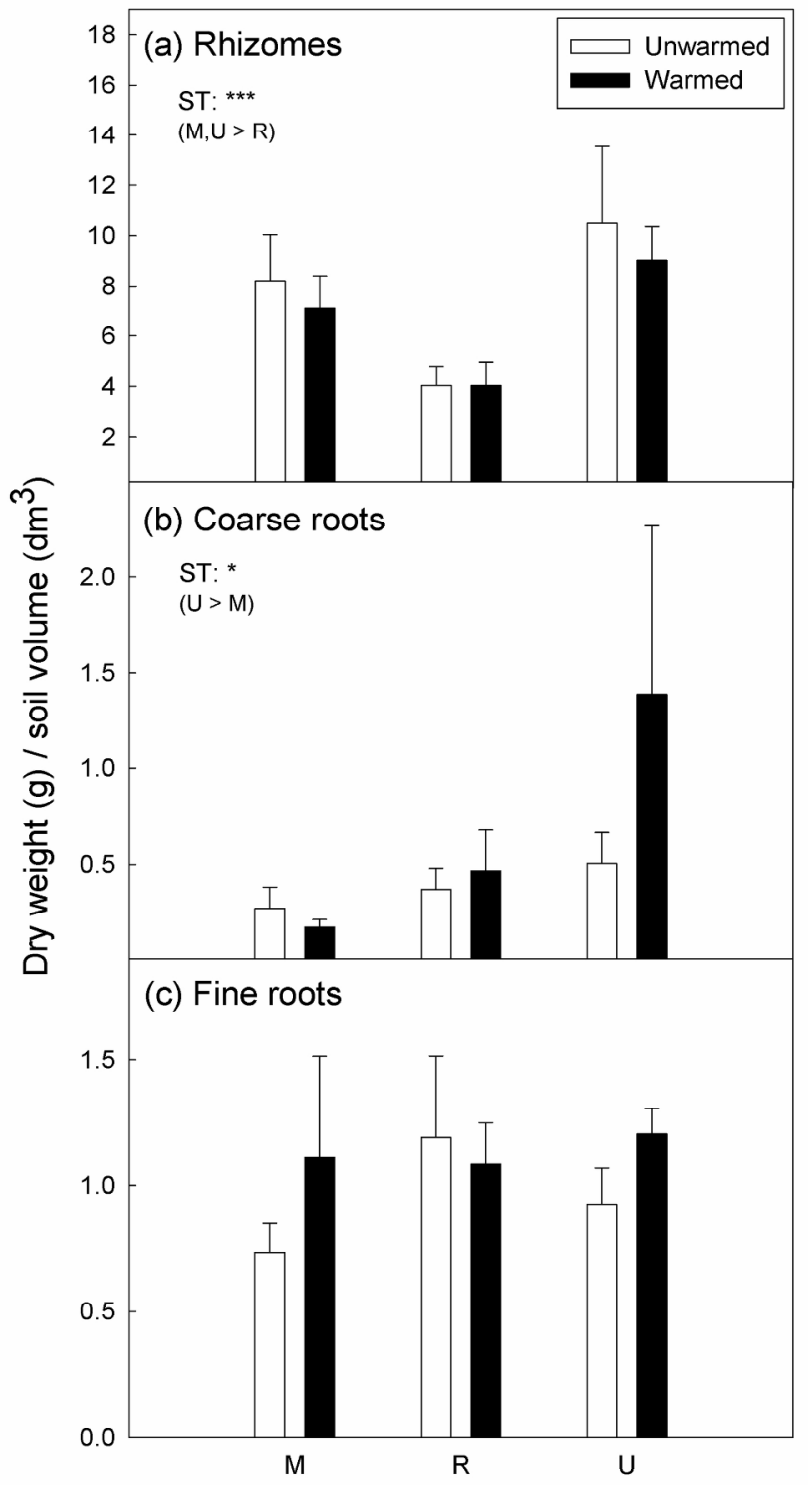

Figure 2. BG biomass per soil volume at the plot scale in different stand types (ST) and warming treatments in September 2013 (W; $n=5$, means +1 SE are shown). Asterisks show significant differences (* marginally significant differences at $0.1>\mathrm{P}>0.05 ; * *$ significant differences at $0.05>\mathrm{P}>0.01 ; * * *$ significant differences at $\mathrm{P}<0.01)$. M: $V$. myrtillus pure stands; R: $V$. myrtillus mixed with $R$. ferrugineum stands; U: $V$. myrtillus mixed with $V$. uliginosum stands. $150 \times 281 \mathrm{~mm}(300 \times 300 \mathrm{DPI})$ 


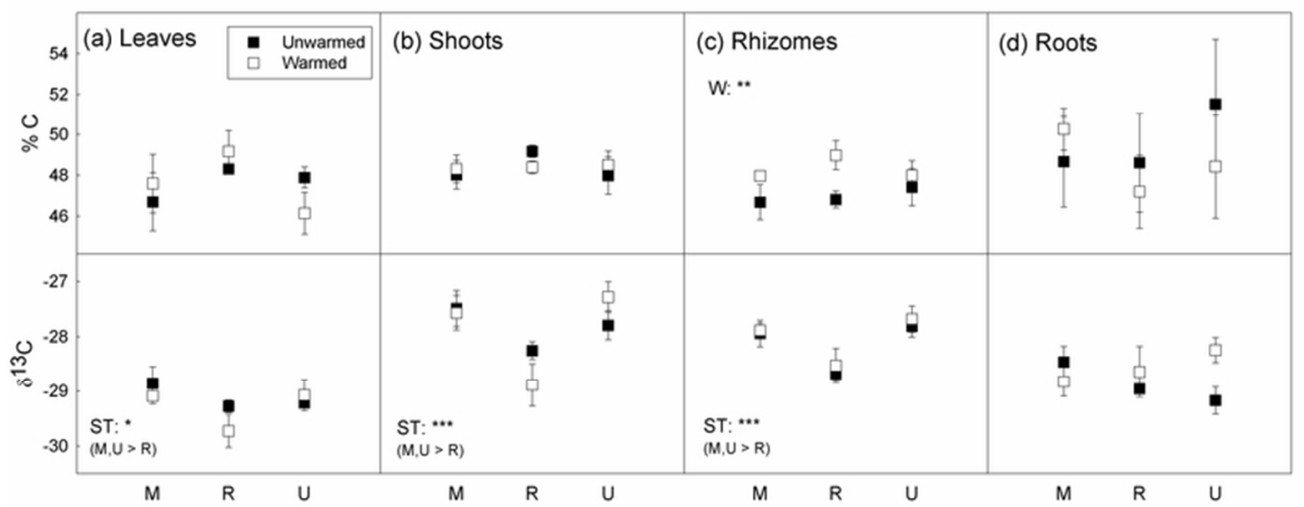

Figure 3. Carbon concentration and $\delta^{13} \mathrm{C}$ of $V$. myrtillus tissues in different stand types (ST) and warming treatments in September 2013 (W; $n=5$, mean +1 SE for concentrations and mean - 1 SE for isotope compositions are shown). Asterisks show significant differences (* marginally significant differences at $0.1>$ $\mathrm{P}>0.05 ; * *$ significant differences at $0.05>\mathrm{P}>0.01 ; * * *$ significant differences at $\mathrm{P}<0.01)$. $\mathrm{M}: \mathrm{V}$. myrtillus pure stands; R: $V$. myrtillus mixed with $R$. ferrugineum stands; U: $V$. myrtillus mixed with $V$. uliginosum stands.

$67 \times 27 \mathrm{~mm}(300 \times 300$ DPI $)$ 


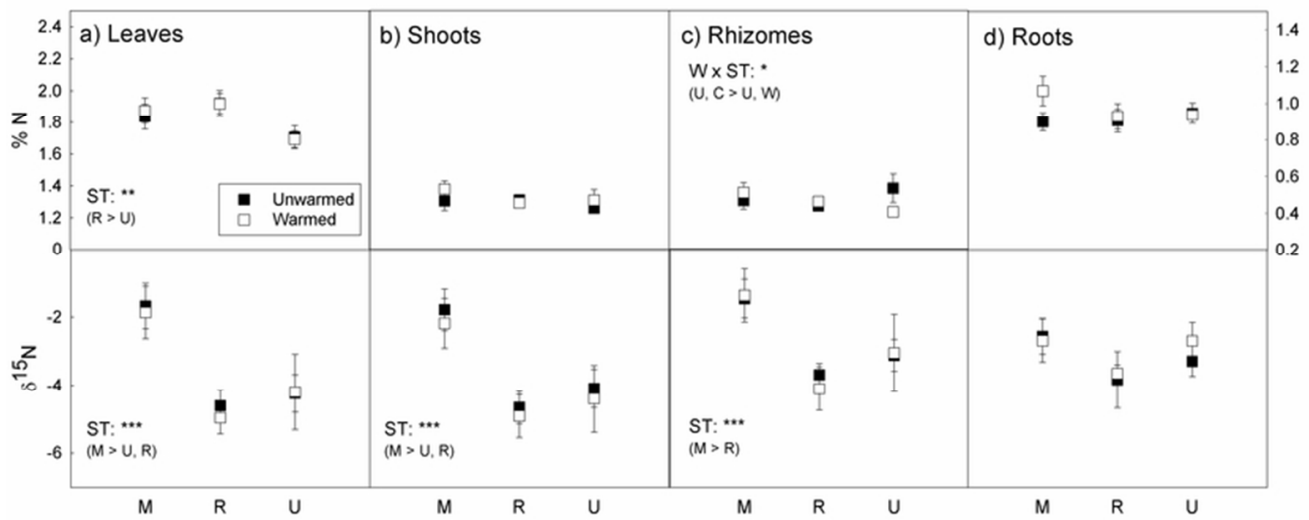

Figure 4. Nitrogen concentration and $\delta^{15} \mathrm{~N}$ of $\mathrm{V}$. myrtillus tissues in different stand types (ST) and warming treatments in September 2013 (W; $n=5$, mean + 1 SE for concentrations and mean - 1 SE for isotope compositions are shown). For $\mathrm{N}$ concentration of rhizomes and roots see the righthand $\mathrm{Y}$-axis scale. Asterisks show significant differences (* marginally significant differences $0.1>\mathrm{P}>0.05$; *** significant differences at $\mathrm{P}<0.01)$. M: $V$. myrtillus pure stands; $\mathrm{R}: V$. myrtillus mixed with $R$. ferrugineum stands; $\mathrm{U}$ : $V$. myrtillus mixed with $V$. uliginosum stands.

$69 \times 29 \mathrm{~mm}(300 \times 300 \mathrm{DPI})$ 

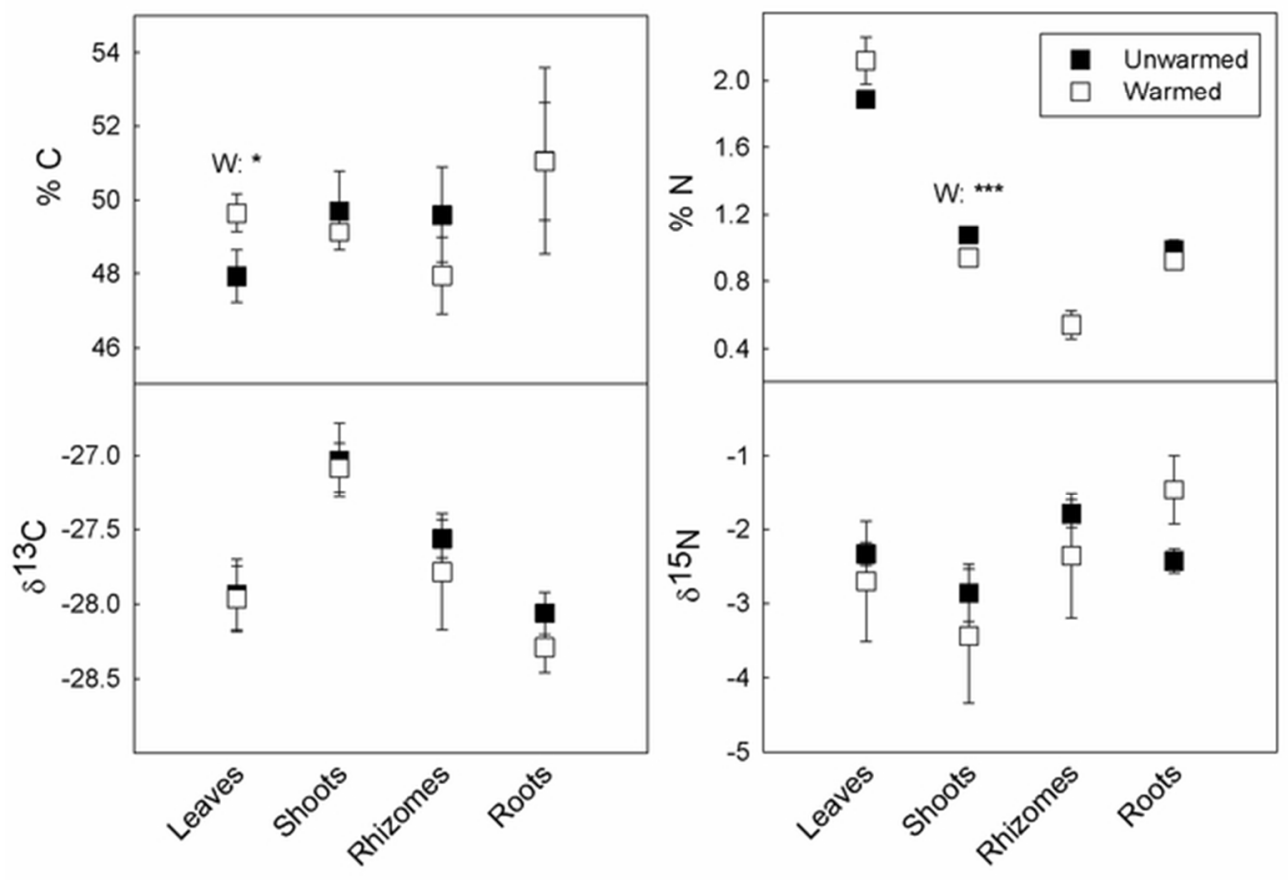

Figure 5. Carbon and nitrogen concentrations and $\delta^{13} \mathrm{C}$ and $\delta^{15} \mathrm{~N}$ of $\mathrm{V}$. uliginosum tissues under different warming treatments in September 2013 (W; $n=4$, mean +1 SE for concentrations and mean - 1 SE for isotope compositions are shown). Asterisks $(* * *)$ show significant differences between warming treatments at $\mathrm{P}<0.01$.

$57 \times 41 \mathrm{~mm}(300 \times 300 \mathrm{DPI})$ 


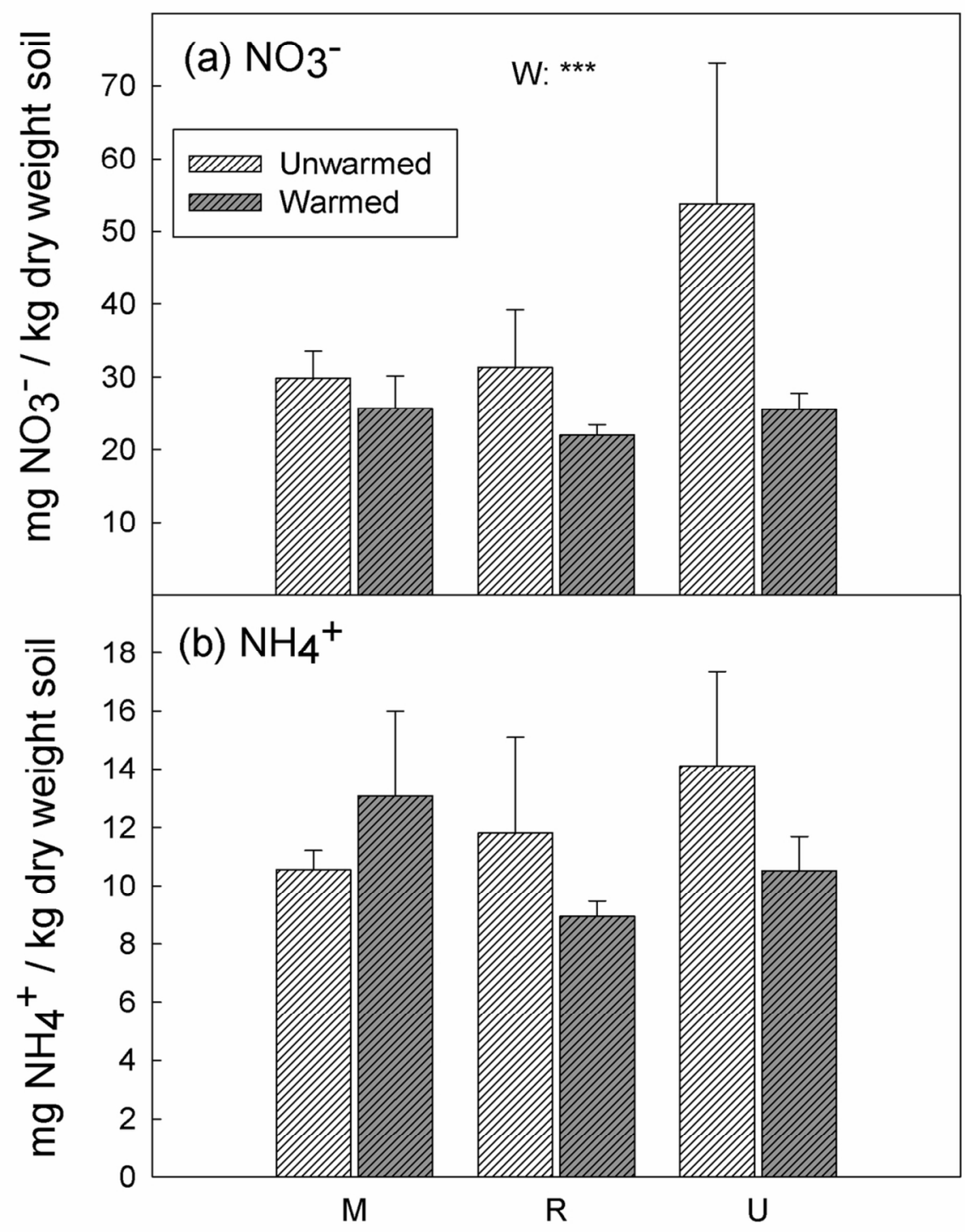

Figure 6. Soil nitrate and ammonia content in our study plots in different stand types (ST) and warming treatments in September 2013 (W; $n=5$, means +1 SE are shown). Asterisks (***) show significant differences at $\mathrm{P}<0.01$. M: $V$. myrtillus pure stands; R: $V$. myrtillus mixed with $R$. ferrugineum stands; U: $V$. myrtillus mixed with $V$. uliginosum stands. $104 \times 136 \mathrm{~mm}(300 \times 300 \mathrm{DPI})$ 


\section{Supplementary Material Appendix 1}
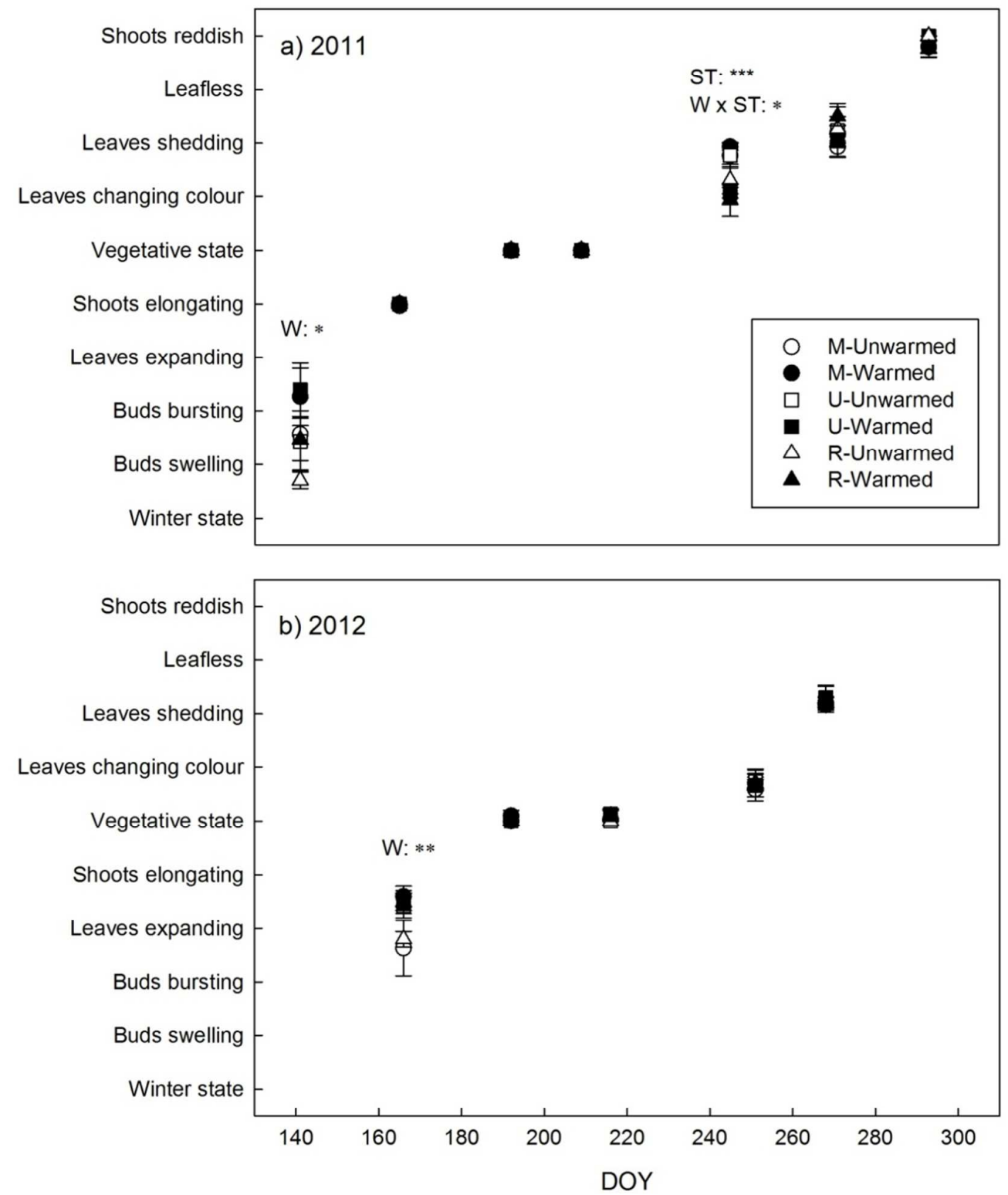

Figure A1. Vegetative phenology (mean phenophase calculated as the average numeric phenophase of six ramets per plot in each visit, day of year: DOY) of Vaccinium myrtillus at the study plots during the growing seasons of 2011 and 2012 under different stand types (ST) and warming treatments (W; $n=5$, means $+1 \mathrm{SE}$ are shown). Asterisks show differences between treatments $(*$ marginally significant differences $0.1>P>0.05$; ** significant differences at $0.05>P>0.01 ; * * *$ significant differences at $P<0.01)$. M: $V$. myrtillus pure stands; R: $V$. myrtillus mixed with $R$. ferrugineum stands; U: V. myrtillus mixed with $V$. uliginosum stands. 


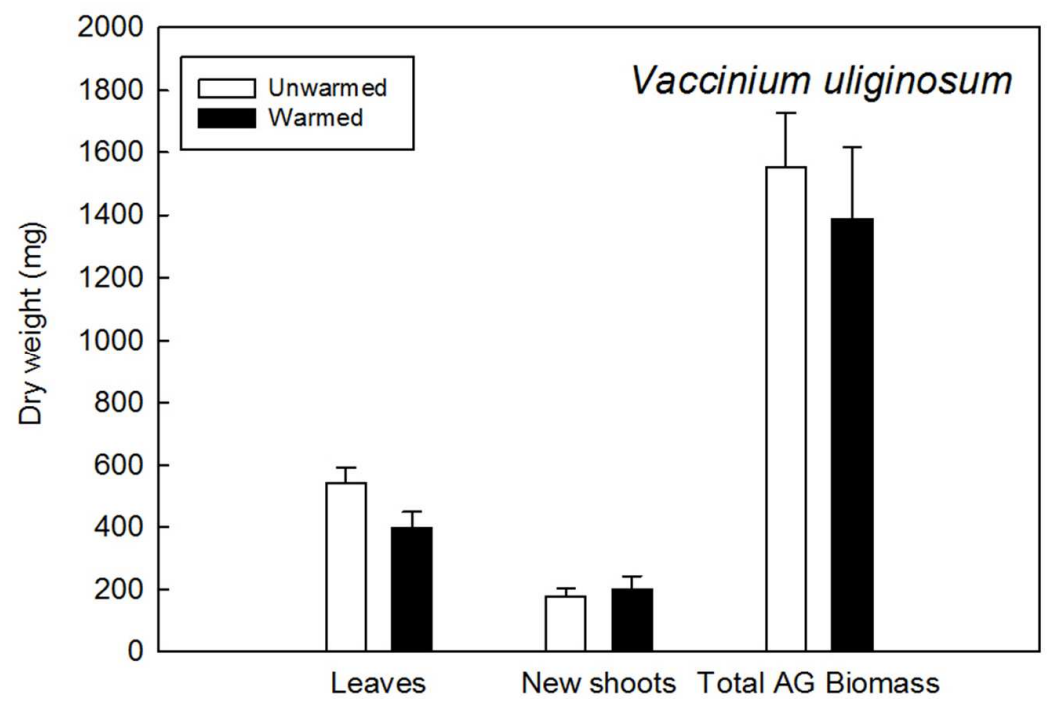

Figure A2. Vaccinium uliginosum above-ground (AG) biomass under different warming treatments in September 2013 ( $n=4$, means +1 SE are shown). There were no significant differences between warming treatments.

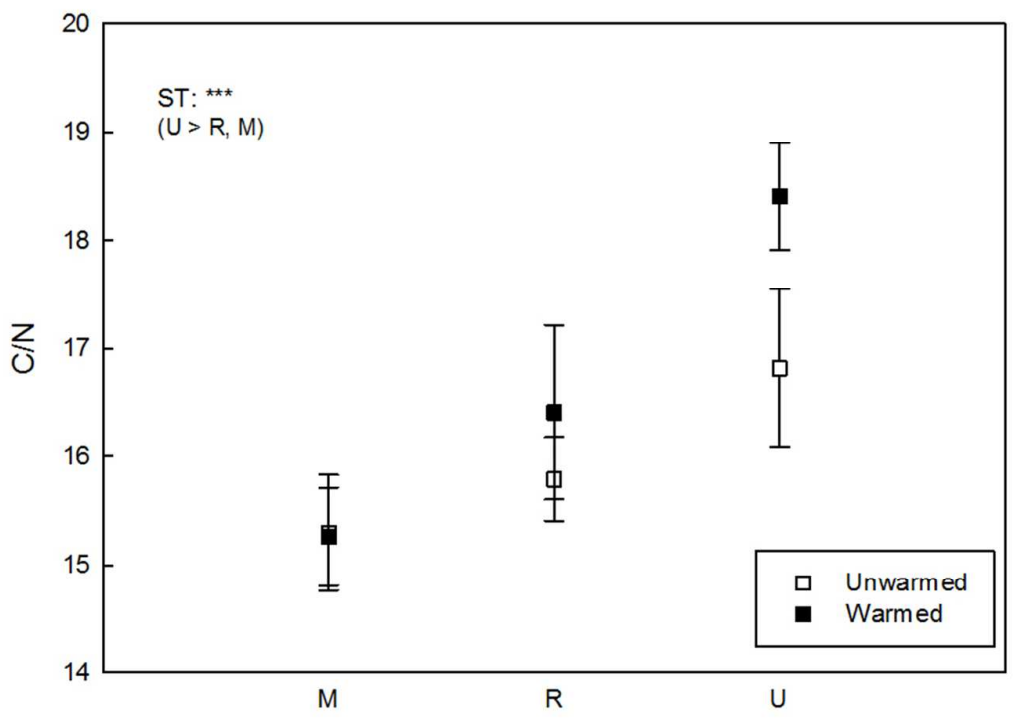

Figure A3. Rhizospheric soil C/N ratio for the different stand types (ST) and warming treatments in September 2013 (W; $n=5$, means $\pm 1 \mathrm{SE}$ are shown). Asterisks (***) show significant differences at $P<0.01$. M: V. myrtillus pure stands; R: V. myrtillus mixed with R. ferrugineum stands; U: V. myrtillus mixed with $V$. uliginosum stands. 
Table A1. Percent cover of the three main shrubs and grasses for the different stand types and warming treatments ( $n=5$, means are shown) in 2011 (left) and 2013 (right). Forbs were only recorded in 2013.

\begin{tabular}{|c|c|c|c|c|c|c|}
\hline Stand type & Warming treatment & V. myrtillus & V. uliginosum & R. ferrugineum & Grasses & Forbs \\
\hline M & Control & 7069 & $0 \quad 0$ & $0 \quad 0$ & $28 \quad 20$ & -8 \\
\hline (V. myrtillus) & Warmed & $68 \quad 83$ & $0 \quad 0$ & $0 \quad 0$ & 2517 & -8 \\
\hline $\mathrm{U}$ & Control & 5243 & $48 \quad 44$ & 02 & 1423 & -7 \\
\hline $\begin{array}{l}\text { (V. myrtillus }+ \\
V . \text { uliginosum })\end{array}$ & Warmed & $41 \quad 34$ & 6668 & 00 & $15 \quad 13$ & -9 \\
\hline $\mathrm{R}$ & Control & $43 \quad 44$ & $0 \quad 1$ & 7382 & 2017 & -6 \\
\hline $\begin{array}{l}\text { (V. myrtillus }+ \\
R . \text { ferrugineum) }\end{array}$ & Warmed & $40 \quad 49$ & $\begin{array}{ll}0 & 0\end{array}$ & 7775 & 1211 & -6 \\
\hline
\end{tabular}

